Cite this Article: Mills, K. A., \& Exley, B. (2014). Time, Space, and Text in the Elementary School Digital Writing Classroom. Written Communication, 31(4), 434-469.

\title{
Time, Space, and Text in the Elementary School Digital Writing Classroom
}

\author{
Kathy A. Mills and Beryl Exley
}

\begin{abstract}
Theorists of multiliteracies, social semiotics, and the New Literacy Studies have drawn attention to the potential changing nature of writing and literacy in the context of networked communications. This article reports findings from a design-based research project in Year 4 classrooms (students aged 8.5-10 years) in a low socioeconomic status school. A new writing program taught students how to design multimodal and digital texts across a range of genres and text types, such as web pages, online comics, video documentaries and blogs. The authors use Bernstein's theory of the pedagogic device to theorize the pedagogic struggles and resolutions in remaking English through the specialization of time, space, and text. The changes created an ideological struggle as new writing practices were adapted from broader societal fields to meet the instructional and regulative discourses of a conventional writing curriculum.
\end{abstract}

\section{Keywords}

Writing, education, communication, New Literacy Studies, pedagogy, Bernstein 
The significance of the "digital turn" has been addressed in more than a decade of research in the New Literacy Studies, synonymous with "new literacies" or the ideological model, with increased attention to new writing and communication practices in digital environments (Barton, 2001; Chandler-Olcott \& Mahar, 2003; Hagood, 2003; Mills, 2010; Street, 2003). The current study of writing practices in elementary school English lessons contributes to the digital strand of research within the New Literacy Studies, which builds on a much longer tradition of sociocultural literacy research of everyday literacy forms among communities (Heath, 1983; Lankshear, 1997; Luke \& Freebody, 1997).

In a digitally networked society, writing in private, public, and civic life involves literacy practices that include a broadened range of genres, modes, and media. Research is needed to investigate how literacy practices in the current times become integrated within writing curricula in the formative years of schooling. We see writing as inclusive of socially organized sign-making practices that make use of both print and digital technologies for producing meanings. This study also responds to a related call of the New London Groupa group that included theorists of New Literacy Studies and social semiotics- to reconceptualize the nature of literacy as "multiliteracies." This call acknowledges the multimodal combination of linguistic, visual, spatial, gestural, and audio modes in texts in response to the changing nature of communication, increased cultural diversity, and the plurality of textual practices (New London Group, 2000).

There are many important features of sign making practices that involve digitally encoded words and images. For example, the New Literacy Studies argues that joint participation in online community practices can facilitate the co-construction of knowledge, such as through the production of e-zines (Courtland \& Paddington, 2008), social networking sites (Horst, 2009), and wikis (Grant, 2006). New Literacy Studies scholars, such as Knobel and Lankshear (2007), have persuasively argued that user-generated web content, podcasts, discussion threads, and blogs encourage "distributed expertise" (see Brown et al., 1993). These modes of discourse are seen as less "expert-dominated" than some conventional forms of writing, supported by changed epistemologies or views about authoritative knowledge (Knobel \& Lankshear, 2007). Other researchers, such as Buckingham (2007), have posited a cultural shift from consumption of new media to creative media production in cultures of participation. Creative media production involves a "hybridization" of textual practices - that is, the blending and modification of literate practices of a culture that may result in the emergence of new text forms and generic structures (Cope \& Kalantzis, 2000).

Lemke (1998), Jewitt (2008), Kress (2000), Unsworth (2006), and other theorists of 
multimodality have argued that these hybridized meanings in multimedia are not just words plus images. Rather, word meanings are modified in the context of image meanings, and vice versa, opening up a wider range of meaning potential for written communication. Similarly, it has been argued that there is heightened interactivity between authors and readers, such as in multimedia authoring, writing on the screen (Ranker, 2008), and online chat (Lam, 2009).

The point is that digital composition now matters in elementary schooling, and the texts to be produced by students in this new age are somewhat different from those of the past. Yet there is little research demonstrating the significant shifts that might be involved for teachers in terms of the temporal and spatial arrangements in digital composition classrooms, and of the changing evaluative requirements for legitimate texts to be produced by students as evidence of "learning" (see Mills, 2010b). These issues are critical, as digital composition is increasingly becoming a central part of what teachers and students do in the literacy classroom. Our research suggests that multimodal and digital design may involve changes not only to the delivery system of instruction, but to the very nature of that instruction.

\section{Research Question and Bernstein's Pedagogic Device}

While the New Literacy Studies provides a rationale for the study, this research into digital composition in the schooling space draws on Bernstein's sociological theory of the pedagogic device as the analytic framework, focusing on the evaluative rules - the specific pedagogic practices that transmit criteria for the acquisition of power, knowledge, and consciousness (Bernstein, 1990).

We used Bernstein's work because he theorized that the pedagogic device constitutes the intrinsic grammar or rules of pedagogic discourse in institutions, and its theoretical and analytic frameworks allow fine-grained analysis of pedagogic practices in social sites (Bernstein, 2000; Christie, 1999). Bernstein's theory has been usefully applied to studies of digital practices over the past two decades (Bennett \& Maton, 2010; Singh, 1993). In our article, attention is drawn to the relations of transmission and acquisition between teacher and student, known theoretically as framing (Bernstein, 2000). Bernstein explains that framing can be understood at two levels. At a theoretical level, it refers to the social relations of a given social division of labor. At a practical level, framing refers to the locus of control over the selection, sequencing, pacing, and criteria of the pedagogic discourse to be acquired in a school or other institutional site (see Exley \& RichardBossez, 2013). 
We draw on Bernstein to theorize the symbolic and pedagogic struggles and resolutions observed as pedagogies for digital writing were introduced into an English curriculum in a low socioeconomic status elementary school in Australia. Specifically, the research aim of this study was to examine time, space, and text in a digital composition program within three Australian elementary school classrooms. The specific research question examined,

What are the pedagogic relations of time, space, and text when teachers and students take up writing in digital contexts of use?

This is important because all social action involves a temporal and spatial dimension, and institutional ways of evaluating social performances, yet there are few studies of digital composition that simultaneously attend to these three dimensions. Bernstein's theory of the pedagogic device explicitly addresses time, space, and text to theorize social action in classrooms, so the decision to investigate these three dimensions is consistent with Bernstein's well-cited theory-a theory that has strong support in the discipline of sociology (see Bernstein, 2000, pp. 35-36). Following Bernstein, time is defined as the partitioning, sequencing, and pacing or rate of expected acquisition of a certain skill — in this study, digital composition. Space refers to the socio-material context of the classroom, such as the social arrangement of bodies, movement, and interactions in a classroom. Text is the product of the instruction and its evaluation, both student dispositions and the artifacts produced, such as the visible ways that students present themselves in classroom contexts and the digital compositions that they create.

\section{Time, Space, and Text}

In pedagogical contexts, "time" can be explicitly or finely differentiated as a marker of certain activities and routines (Bernstein, 2000). At the level of curriculum, time is a key concept that divides the school curriculum into subjects, linearly represented as hours and minutes per lesson, school day, school week, quarter, and year (Adams, 1995). As such, this projection of time provides points of reference for locating, coordinating, and recording pedagogical social action.

Spatial theory is a growing focus of literacy research (Comber \& Nixon, 2008; Leander \& Sheehy, 2004), with new understandings to be developed in digital contexts of use (Leander, 2003). Following the work of Soja (1989), we see the organization of the classroom space as a social product, since it arises from purposeful social practice. Social space includes both individual and collective social action, although institutional contexts require the co- 
coordinated action of individuals to converge at specified times and places (Lefebvre, 1991). "Space" also includes the physical or architectonic arrangement of objects and people at the spatial level, which are concrete manifestations of social classifications experienced socially.

We draw on theorizations of "text" as the product of pedagogizing knowledge, and its evaluative criteria, including both digital texts and the student as text (Bernstein, 2000). This includes expectations of how students should posture themselves, move, and perform as learners in the classroom. We are interested in extending understanding of written composition in digital contexts of use in the elementary English curriculum.

\section{Policy Context and Implications}

Research in other predominantly English-speaking countries has demonstrated that mandated testing of writing and literacy, such as the No Child Left Behind testing in the United States (Lam, 2009), frequently positions digitally mediated writing somewhat peripherally to English curriculum content (Applebee \& Langer, 2009). Since 2008, Australian school students have been required to participate in national testing - the National Assessment Program - Literacy and Numeracy (NAPLAN; Australian Curriculum, Assessment and Reporting Authority [ACARA], 2012). NAPLAN is a program of national tests that includes writing and language conventions (spelling, grammar, and punctuation), to give schools and systems the ability to compare student achievement against national standards. Writing skills testing has become discursively constructed as a race in which states and territories, schooling systems, and categories of students are positioned in opposition to one another by the media and the Australian government via the "My School" website (ACARA, 2012).

There was also a recent shift from state English curricula to a centralized Australian English Curriculum that includes multimodal text creation using software (ACARA, 2014). This re-regulation of schooling - when central governments reclaim control of education (Helgøy, Homme, \& Gewirtz, 2007) - is important for understanding the research context of our analysis of time, space, and text at multiple levels of power (Bernstein, 2000).

\section{Site Selection and Description}

Logan City, the location of the school, was selected because it is a central region for immigrants (25.3\% of population), with a high proportion of persons who speak a language other than English at home (17.9\%; Australian Bureau of Statistics, 2006). Unemployment is significantly higher in the Logan area (5.8\% of adults 15 years and older) than in the nearest 
Logan area (5.8\% of adults 15 years and older) than in the nearest city, Brisbane (4.4\%). In addition, $20.9 \%$ of households are one-parent families, versus $15.8 \%$ in the Australian population. In Logan, $18 \%$ of occupied residential rental dwellings belong to the State Housing Authority, which is higher than the state-wide proportion (14.9\%; Australian Bureau of Statistics, 2006). These features of Logan City made it an appropriate site for the project focused on enabling socially disadvantaged and culturally diverse students to gain access to writing and communication skills relevant to the globalized digital environment.

The school was chosen because it qualified for the federal government's Low SocioEconomic Schools National Partnership program, which provides additional funding and resources to the lowest achieving schools (Council of Australian Governments, 2009). The reward-based payments are continued only on improvements in performance against agreed indicators, with higher levels of accountability and increased pressure on principals, teachers, and parents to raise NAPLAN test scores.

\section{Student Cohort Selection and Description}

Student cohort selection met two criteria—cultural heterogeneity and socio-economic disadvantage. Year 4 (students aged 8.5 to 10 years) was chosen because research has reported evidence of the "Fourth Grade Slump"- an achievement gap between students of low-income and middle-income families in literacy learning and writing, particularly evident in fourth grade and beyond (Suhr, Hernandez, Grimes, \& Warschauer, 2010). The decision to focus on a single year-level cohort was based on the manageability of the literacy project to optimize teaching support personnel (literacy support and research assistant) and new technologies (e.g., 12 laptops on a trolley, 12 digital cameras).

The 85 student participants included Aboriginal and Torres Strait Islander students (5\%), children of Pacific Island origin, and English as a second language learners, as well as students ascertained as having significant learning disabilities who qualified for specialist learning support (7\%). Over $90 \%$ of students are identified as being in the bottom quartile according to the nation's Index of Community Socio-Educational Advantage, with only $5 \%$ in the lower-middle quartile and $0 \%$ in the top quartile.

In Australia, national testing is administered to students in Years 3, 5, 7, and 9. The Year 4 cohort NAPLAN scores for the previous testing year in reading, writing, spelling, and grammar were classified as "substantially below" both the national average and the average for statistically similar schools in the NAPLAN statistics (Ministerial Council for Education, Early Childhood Development and Youth Affairs [MCEECDYA], 2012). 


\section{Teacher Selection and Description}

The teacher participants who volunteered to participate in this descriptive case study were three Year 4 teachers, Margaret, Jessica, and Vivian (pseudonyms), who taught the 85 students in the cohort. Making contact initially through the principal, we conducted whole school professional development sessions to meet the teachers and determine their interest in the project. The principal gave teachers the option of moving to Year 4 from other grades, or remaining in Year 4 to be involved in the project. The teachers came to the project with varied levels of teaching experience. Margaret had taught for 30 years, and Jessica and Vivian were beginning their 2 nd year of teaching. The two recently graduated teachers were familiar with using a range of technologies in their classrooms, such as educational resources and games on the World Wide Web, but had little specialist expertise in digital filmmaking genres, image composition, digital photography, digital video editing techniques, podcasting, web profile design, embedding widgets in web pages, or blogging. In the early phases of the research, Margaret frequently expressed her discomfort with using new technologies in the classroom, but took up many opportunities to transform her existing literacy program.

\section{Technology Infrastructure}

Prior to the research project, each classroom had four Apple desktop computers that were too old to be networked to the school intranet. One interactive whiteboard was shared between Jessica's and Vivian's classes, and Margaret's class used a data projector propped up on a desk with a makeshift screen. In the second year, project funds were used to purchase 12 Apple MacBook notebook computers on a trolley and 12 digital flip cameras (compact video cameras). The school also invested in a lab space with 25 Apple computers that could be connected to the school intranet system to be shared by all classes in the school.

\section{Description of Collaboration with Teachers}

In the first year of the project, the research team offered after-school digital workshops to introduce interested teachers to new digital software and new pedagogies. We also spent some time in classes each week teaching digital skills to small groups of students, who then became peer tutors. The purpose of this phase of the research was to build trust with the teacher participants, introduce the teachers to new digital pedagogies for writing, and collaboratively plan the program for the following year. In the last quarter of the first year, Author 1 was the 
main participant observer in the Year 4 classrooms for 3 days per week, gaining the teacher's trust, working with small groups, or assisting individuals with reading, while collecting baseline observations of the teachers' existing enactment of the English curriculum. Author 2 also made regular visits to the school, providing in-class support for the teachers. Baseline data were recorded at the end of each visit to the school, and posted remotely as a web log accessible only to the researchers. The data were analyzed as described in the Data Analysis section below. A recurring theme in this early phase was that the teachers did not attend to multimodality in the writing program, but focused on activities such as vocabulary worksheets, forming sentences from spelling lists, and writing narratives in copybooks on teacher-directed topics. Some students used the computers for word processing final drafts, and CD-ROM educational software for basic skill repetition work. The English curriculum drew predominantly upon basic skills approaches to literacy learning, including when writing with pencils or when using the computers for writing.

The following year, the teachers began the new multimodal and multimedia authoring program with a new cohort of students. In Semester 1, 40 one-hour lessons per classroom (120 lessons across the cohort) were planned and implemented by a team composed of the three participating classroom teachers, the first author - a literacy researcher/lecturer from the university - and a specialist media arts teacher chosen for her expertise in media production. In the first two terms of the new literacy curriculum, the specialist media arts teacher and literacy lecturer helped the teachers to plan multimodal design and digital media production lessons, and modeled or co-taught these lessons with teachers, while the classroom teachers maintained aspects of the classroom organization and management. The literacy researcher facilitated teamwork, supported teacher decision making and student learning, and collected data.

The program taught students how to design multimodal and digitally written texts across a range of genres and text types. The students worked individually and collaboratively to produce web pages sharing lengthy narratives and personal profiles, and inserted widgets such as maps and birthday count-downs. They handwrote scripts and recorded audio-visual podcasts in the school's sound proof "blue room" to deliver information reports. The teachers taught narrative writing activities through online comic creation (makebeliefscomix.com). Students wrote scripts and created video documentaries interviewing literary characters from novels, and wrote web logs to recount everyday events and learning experiences, such as documenting their Lego robotic experiments in science.

Many of these creative tasks were complex, involving new metalanguages to describe multimodal texts (e.g., shot types, cutaways, transitions), and technical proficiencies with a suite of Apple software products. For example, the micro-documentary lessons included 
modeling and analysis of the features of micro-documentaries, responding to children's literature to imagine alternative plots, classifying shot types, learning digital camera skills, drawing story- boards, writing scripts, filming workshops, digitally editing movies, recording voice-overs, and presenting movies to the school community. The collaborative planning and implementation process involved the following steps:

1. Researchers introduced teachers to a broad range of possible media projects via afterschool workshops and year level meetings.

2. Teachers selected their preferred projects and media applications to suit their writing program objectives and text types.

3. Researchers drafted the program and modified it with teacher feedback.

4. Teachers and researchers made modifications to the plan and during implementation.

Figure 1 provides an overview of the Semester 1 plan of the new literacy curriculum to address iMovie (making micro-documentaries) and iWeb (creating web pages) in the first and second quarters.

In the second 6 months of the second year, the responsibility for teaching the digital writing practices was progressively released to the classroom teachers, who each took the program in unique directions. The researcher and media specialist continued to maintain a presence in the three classrooms for 6 hours per week, providing technical and writing support. Toward the end of this semester, the teachers were addressing new writing practices without assistance, revisiting and extending the practices introduced in the first semester. For example, Margaret extended the students' skills with website design, using templates to display narratives. With less scaffolding provided by the software templates, students had to attend to the original formatting of the visual and spatial dimensions of their web pages. She also extended their writing skills in web pages to different text types, moving from descriptive personal profiles and recounts, to narratives with complex settings, character descriptions, and plots.

\section{Data Collection}

The data reported here include baseline data collected during the participant observation phase and during the implementation of the new learning experiences collected intensively over the project duration. We generated three data sets: observations, discussion with participants, and artifact collection. Observations, discussion, and artifact data are summarized in the data collection schedule (see Figure 2). 


\begin{tabular}{|c|c|c|c|}
\hline \multicolumn{2}{|c|}{ iWeb Skills Sequence } & \multicolumn{2}{|c|}{ iMovie Skills Sequence } \\
\hline About Me Page & $\begin{array}{l}\text {-Select background from a } \\
\text { template and text } \\
\text {-Delete unwanted text from } \\
\text { template } \\
\text {-Use of Photobooth application } \\
\text { to take photos via webcam } \\
\text {-Add photos to page } \\
\text {-Add a countdown widget }\end{array}$ & $\begin{array}{c}\text { Story- } \\
\text { boarding }\end{array}$ & $\begin{array}{l}\text { - Learn to identify and apply a } \\
\text { range of shot types } \\
\text { - Storyboard conventions such } \\
\text { as frame, vision and sound } \\
\text { - Scripts to match storyboards }\end{array}$ \\
\hline Blog Page & $\begin{array}{l}\text { - Typing skills } \\
\text { - Select fonts and colours of text } \\
\text { - Navigate the 'Entries' and } \\
\text { 'Archive' pages }\end{array}$ & Filming & $\begin{array}{l}\text { - Camera use such as turning } \\
\text { on and off, zooming, playback } \\
\text { - Shot selection } \\
\text { - Film using storyboard } \\
\text { /planning sequences }\end{array}$ \\
\hline Podcast Page & $\begin{array}{l}\text {-Use of 'Garageband' } \\
\text { application } \\
\text { Record and edit podcasts } \\
\text { Drag pictures to a different } \\
\text { application } \\
\text { - Export podcast from Garage- } \\
\text { band into iWeb }\end{array}$ & \multirow[t]{2}{*}{ Editing } & $\begin{array}{l}\text { - Create new iMovie project } \\
\text { - Import footage taken on } \\
\text { cameras } \\
\text { - Crop clips } \\
\text { Add clip to the timeline } \\
\text { - Change the position of the } \\
\text { clip in the timeline } \\
\text { - Add special effects such as } \\
\text { transitions and visual effects } \\
\text { including colour palette } \\
\text { changes }\end{array}$ \\
\hline Movie Page & $\begin{array}{l}\text { - Drag iSight widget over to } \\
\text { iWeb } \\
\text { - Record and delete movies } \\
\text { - Play, pause and adjust volume } \\
\text { levels of movie }\end{array}$ & & $\begin{array}{l}\text { - Add voiceovers, sound } \\
\text { effects and music to their } \\
\text { timeline } \\
\text { - Add titles, subtitles and end } \\
\text { credits to projects } \\
\text { Cutaways added into the } \\
\text { middle of a clip } \\
\text { - Export movie into AVI } \\
\text { format for sharing }\end{array}$ \\
\hline
\end{tabular}

\section{Figure 1. Semester 1 overview}

Observations included participant observation of print-based writing lessons in the first year and focused observations of all new writing lessons conducted in the three classrooms in the second year ( 2 hours per class per week, 3 classes, 40 school weeks per year). Each focused lesson observation was two to three pages in length with detailed description and included excerpts of direct speech of the participants. In addition, researcher field notes based on semistructured, audio-recorded postlesson teacher reflections and other observations of time, space, and text in the broader English curriculum were recorded at the end of each day of fieldwork.

Data collection involving dialogue with participants included researcher blogs, teacher focus groups, teacher-researcher semistructured interviews, and teacher-researcher planning meetings.

Teacher focus groups were conducted at the beginning and end of each school quarter and audio-recorded. The first focus group gained the teachers perspectives of their pedagogies, literacy routine 


\begin{tabular}{|c|c|c|c|c|}
\hline $\begin{array}{l}\text { Project } \\
\text { Timeline }\end{array}$ & Project Phase & Teaching \& Learning & Data Collection & Data Analysis \\
\hline $\begin{array}{l}\text { Year } 1 \\
\text { Oct-Dec }\end{array}$ & $\begin{array}{ll}\text { - } & \text { Building } \\
& \text { Rapport \& } \\
\text { - } & \text { Baseline Data } \\
\text { Collection }\end{array}$ & $\begin{array}{l}\text { Delivered full day } \\
\text { whole school } \\
\text { professional } \\
\text { development sessions } \\
\text { twice } \\
\text { Delivered after } \\
\text { school year } 4 \text { level } \\
\text { teacher workshop } \\
\text { - Provided in-class } \\
\text { literacy support } 3 \\
\text { days per week for } 3 \\
\text { classes of Yr } 4 \\
\text { - Attended/ recorded } \\
\text { all Yr } 4 \text { level } \\
\text { planning meetings } \\
\text { Archived writing } \\
\text { samples from each } \\
\text { student } \\
\text { Digital work sample } \\
\text { from each student }\end{array}$ & $\begin{array}{l}\text { - Researcher daily field } \\
\text { notes written up as } \\
\text { web log } \\
\text { - Semi-structured } \\
\text { teacher interview } \\
\text { following schedule of } \\
\text { questions }\end{array}$ & $\begin{array}{l}\text { - Coded } \\
\text { researcher } \\
\text { field } \\
\text { notes/web } \\
\text { log } \\
\text { - Coded semi- } \\
\text { structured } \\
\text { teacher entry } \\
\text { interview }\end{array}$ \\
\hline $\begin{array}{l}\text { Year } 2 \\
\text { Jan- } \\
\text { March }\end{array}$ & $\begin{array}{l}\text { - Implementation } \\
\text { \& Evaluation } \\
\text { Phase } 1\end{array}$ & $\begin{array}{l}\text { - Audio-recorded } \\
\text { fortnightly teacher } \\
\text { year-level planning } \\
\text { meetings with } \\
\text { researchers } \\
\text { Archived all student } \\
\text { writing and digital } \\
\text { work samples } \\
\text { produced during the } 6 \\
\text { hours per week } \\
\text { Designed and applied } \\
\text { criterion-referenced } \\
\text { assessments for } \\
\text { students' digital work } \\
\text { samples }\end{array}$ & $\begin{array}{l}\text { Lesson observations: } \\
3 \text { classes/2x } 1 \mathrm{hr} \\
\text { lessons per week } \\
\text { (Total } 6 \mathrm{hrs} / \mathrm{wk}) \\
\text { - } \text { Semi-structured } \\
\text { teacher interviews, } \\
\text { audio-recorded, to } \\
\text { reflect after each } \\
\text { lesson }(5 \text { minutes per } \\
\text { teacher) } \\
\text { Teacher reflective } \\
\text { diary completed once } \\
\text { per quarter using } \\
\text { schedule of questions } \\
\text { addressing time, } \\
\text { space and text. }\end{array}$ & $\begin{array}{ll}\text { - } & \text { Coded } \\
\text { Lesson } \\
\text { Observations } \\
\text { - } \text { Coded } \\
\text { transcribed } \\
\text { teacher } \\
\text { interviews } \\
\text { - Coded } \\
\text { teacher } \\
\text { reflective } \\
\text { journals } \\
\text { - Analyzed } \\
\text { frequency of } \\
\text { themes }\end{array}$ \\
\hline $\begin{array}{l}\text { Year } 2 \\
\text { April- } \\
\text { June }\end{array}$ & $\begin{array}{l}\text { - Implementation } \\
\text { \& Evaluation } \\
\text { Phase } 2\end{array}$ & As above & As above & As above \\
\hline $\begin{array}{l}\text { Year } 2 \\
\text { July- } \\
\text { Aug }\end{array}$ & $\begin{array}{l}\text { - Implementation } \\
\text { - \& Evaluation } \\
\text { Phase } 3\end{array}$ & As above & As above & As above \\
\hline $\begin{array}{l}\text { Year } 2 \\
\text { Sept-Oct }\end{array}$ & $\begin{array}{l}\text { - Implementation } \\
\text { \& Evaluation } \\
\text { Phase } 4\end{array}$ & As above & As above & As above \\
\hline
\end{tabular}

Figure 2. Data Collection Schedule.

and teaching of digital text production in the English curriculum. The subsequent focus groups gained 
teacher perspectives on the implementation phase of the project, providing opportunity to troubleshoot any issues of concern with the researcher-teacher collaboration. The final focus group addressed teachers' reflections on the digital and multimodal composition program.

The teacher-research planning meetings were conducted six times and audio-recorded. The purpose was to collaboratively plan each 10-week unit of the new curriculum, and exchange resources, pedagogical knowledge, and expertise in multimodal and digital text production.

The teachers completed reflective journal entries on their perceptions of classroom time, space, and text in relation to the digital composing lessons, collected at three data points in the second year of the project (beginning, middle, exit) for each teacher. These were collected as word documents that contained a schedule of 18 questions, with 6 items matched to each of the three themes (e.g., time - "How has the introduction of the new learning experienced influenced the allocation of time within your English curriculum").

Artifact data included student print and digital artifacts (224 artifacts), including writing samples collected before and during the project. Digital products from all students were archived, such as student-created web pages, drawings demonstrating different shot types (e.g., close-up, medium, long shot), storyboards, movie scripts, podcasts (audio and video recordings displayed on the web), online comics, and micro-documentaries.

\section{Data Analysis}

We developed and applied a coding scheme for the full corpus of lesson observations, researcher blog, teacher journals, transcripts of teacher interviews, and meetings. We used Carspecken's (1996) hierarchical coding, attending to Bernsteinian (2000) categories of the pedagogic device. Specifically, we analyzed how the pedagogic discourse functioned within a given time (pacing), text (product), and space (context). We developed an analytic framework to elaborate Bernstein's the rules of the "pedagogic device" in writing instruction using digital tools, and then reduced the categories to those that recurred most frequently. Figure 3 provides a list of the codes with examples of classroom observations for each category, and the three larger categories under which the codes were regrouped - time, space, and text.

Figure 3 represents the refined coding system that focuses on the criteria that govern the pedagogical practices, that is, instructional and regulative discourses, and their temporal, spatial, and textual orientation (Bernstein, 2000). We also observed how the teachers and the research team evaluated the students' performances and competencies in their written products. We applied these inductive coding procedures to the observational data sets and the data sets that involved dialogue with the participants. 


\begin{tabular}{|c|c|c|}
\hline \multicolumn{3}{|r|}{ Time } \\
\hline $1 \mathrm{a}$ & Time allocated to reading & $\begin{array}{l}\text { E.g. Students are given time to read a child's blog on the } \\
\text { internet. }\end{array}$ \\
\hline $1 b$ & $\begin{array}{l}\text { Time allocated to reading } \\
\text { comprehension }\end{array}$ & $\begin{array}{l}\text { E.g. After reading a chapter of The BFG, by Roald Dahl, } \\
\text { students create a set of storyboard frames to retell the events } \\
\text { as a film. }\end{array}$ \\
\hline $1 \mathrm{c}$ & $\begin{array}{l}\text { Time allocated to speaking and } \\
\text { listening }\end{array}$ & $\begin{array}{l}\text { E.g. After viewing a film, students discuss the camera } \\
\text { techniques in small groups. }\end{array}$ \\
\hline $1 d$ & $\begin{array}{l}\text { Time allocated to teaching visual } \\
\text { metalanguage }\end{array}$ & $\begin{array}{l}\text { E.g. Students classify still images into } 6 \text { categories of shot } \\
\text { types (e.g. long, medium, close-up). }\end{array}$ \\
\hline $1 \mathrm{e}$ & Time allocated to writing & $\begin{array}{l}\text { E.g. Students write scripts for micro-documentaries, } \\
\text { including interview questions. }\end{array}$ \\
\hline 1f & $\begin{array}{l}\text { Time allocated to learning } \\
\text { software systems }\end{array}$ & $\begin{array}{l}\text { E.g. The teacher demonstrates how to insert cut-a-ways in } \\
\text { interview footage using Apple iMovie software. }\end{array}$ \\
\hline $1 \mathrm{~g}$ & $\begin{array}{l}\text { Time allocated to learning the } \\
\text { technology hardware and intranet }\end{array}$ & $\begin{array}{l}\text { E.g. Students log on to the school server using correct } \\
\text { password. Storing laptops. }\end{array}$ \\
\hline $1 \mathrm{~h}$ & $\begin{array}{l}\text { Time apportioned to making } \\
\text { regulative discourse explicit }\end{array}$ & $\begin{array}{l}\text { E.g. Teacher spends } 7 \text { minutes rehearsing how children } \\
\text { should walk into the library. }\end{array}$ \\
\hline $1 \mathrm{i}$ & $\begin{array}{l}\text { Time apportioned to visual text } \\
\text { creation }\end{array}$ & $\begin{array}{l}\text { E.g. Students create individual profiles about themselves } \\
\text { using Apple iWeb software. }\end{array}$ \\
\hline $1 \mathrm{j}$ & Time apportioned to viewing texts & $\begin{array}{l}\text { E.g. Children watch } 3 \text { short micro-documentaries that apply } \\
\text { contrasting camera techniques. }\end{array}$ \\
\hline $1 \mathrm{k}$ & $\begin{array}{l}\text { Time apportioned to transmitting } \\
\text { the textual features and functions }\end{array}$ & $\begin{array}{l}\text { E.g. Wait time as texts are rendered or saved to an external } \\
\text { flash drive. }\end{array}$ \\
\hline 11 & $\begin{array}{l}\text { Time specialised by the use of } \\
\text { digital tools }\end{array}$ & $\begin{array}{l}\text { E.g. When equipment has to be shared, each student is } \\
\text { allocated a } 5 \text { minutes time frame. }\end{array}$ \\
\hline $1 \mathrm{~m}$ & $\begin{array}{l}\text { Time strongly framed or } \\
\text { controlled by teacher }\end{array}$ & $\begin{array}{l}\text { E.g. Teacher lists tasks for students to complete in a } \\
\text { specified time frame. }\end{array}$ \\
\hline ln & $\begin{array}{l}\text { Time weakly framed or controlled } \\
\text { by teacher }\end{array}$ & $\begin{array}{l}\text { E.g. Towards the end of the media unit, the teacher asks } \\
\text { each group of students what they need to accomplish during } \\
\text { a particular lesson. }\end{array}$ \\
\hline
\end{tabular}

\section{Figure 3 List of Codes with Examples}




\begin{tabular}{|c|c|c|}
\hline \multicolumn{3}{|r|}{ Space } \\
\hline $2 \mathrm{a}$ & $\begin{array}{l}\text { Space determined by individual } \\
\text { needs of user }\end{array}$ & $\begin{array}{l}\text { E.g. When filming, students consider the background required } \\
\text { for particular shots. }\end{array}$ \\
\hline $2 b$ & $\begin{array}{l}\text { Space specialised by use of the } \\
\text { tools }\end{array}$ & $\begin{array}{c}\text { E.g. Students are required to move away from other groups } \\
\text { when audio recording to avoid noise interference in the final } \\
\text { product. }\end{array}$ \\
\hline $2 \mathrm{c}$ & $\begin{array}{l}\text { Space is constraining for use of } \\
\text { digital tools }\end{array}$ & $\begin{array}{l}\text { E.g. There is nowhere to recharge the trolley of laptops in the } \\
\text { classroom. }\end{array}$ \\
\hline $2 d$ & $\begin{array}{l}\text { Space is enabling for use of } \\
\text { digital tools }\end{array}$ & $\begin{array}{l}\text { E.g. The classroom layout in the lesson allowed the teacher } \\
\text { and children to use the digital tools without spatial constraints. }\end{array}$ \\
\hline $2 \mathrm{e}$ & $\begin{array}{l}\text { Space strongly framed or } \\
\text { controlled by teacher } \\
\text { (Teacher has a high degree of } \\
\text { control of student movement) }\end{array}$ & E.g. Students seated upright at desks, all eyes on teacher. \\
\hline $2 \mathrm{f}$ & $\begin{array}{c}\text { Space weakly framed or } \\
\text { controlled by teacher } \\
\text { (Students have a high degree of } \\
\text { control over use of space) }\end{array}$ & $\begin{array}{l}\text { E.g. Students are permitted to climb trees or amble playground } \\
\text { to shoot particular scenes. }\end{array}$ \\
\hline
\end{tabular}

\section{Figure 3 List of Codes with Examples}




\begin{tabular}{|c|l|l|}
\hline \multicolumn{2}{|l|}{ Text } \\
\hline 3a & $\begin{array}{l}\text { Pedagogic text is correct use of the } \\
\text { digital interface }\end{array}$ & $\begin{array}{l}\text { E.g. Teacher moves to next instruction about digital } \\
\text { editing when all students have shifted 3 movie clips to the } \\
\text { timeline using iMovie. }\end{array}$ \\
\hline 3b & $\begin{array}{l}\text { Pedagogic text is text to be produced } \\
\text { by acquirer }\end{array}$ & $\begin{array}{l}\text { E.g. Students put hands on head when they've finished } \\
\text { making a piece of text and teacher inspects that text for } \\
\text { particular inclusions. }\end{array}$ \\
\hline 3c & $\begin{array}{l}\text { Evaluative rule is demonstration of } \\
\text { technical procedures }\end{array}$ & $\begin{array}{l}\text { E.g. Students must correctly insert saved images from } \\
\text { USB to their Apple iWeb page. }\end{array}$ \\
\hline $3 \mathrm{~d}$ & $\begin{array}{l}\text { Evaluation is based on explicit } \\
\text { criteria for product }\end{array}$ & $\begin{array}{l}\text { E.g. The quality of student movies is assessed using a } \\
\text { detailed criteria checklist. }\end{array}$ \\
\hline 3e & Regulative discourse explicit & $\begin{array}{l}\text { E.g. There is a behavioural disruption or shift in the } \\
\text { classroom order, and the teacher overtly redirects student } \\
\text { behaviour. }\end{array}$ \\
\hline $3 \mathrm{f}$ & Regulative discourse implicit & $\begin{array}{l}\text { E.g. Students work for quietly and productively at laptops } \\
\text { without reminders about behaviour because expectations } \\
\text { are established. }\end{array}$ \\
\hline 4a & $\begin{array}{l}\text { Discourse - recognition and } \\
\text { realisation rules for legitimate texts } \\
\text { are explicit }\end{array}$ & $\begin{array}{l}\text { E.g. Teachers provide a sample text and talk to students } \\
\text { about why it is a good piece of text. }\end{array}$ \\
\hline 4b & $\begin{array}{l}\text { Discourse }- \text { recognition rules are not } \\
\text { explicit for linguistic features }\end{array}$ & $\begin{array}{l}\text { E.g. Students create paragraphs of text in web page } \\
\text { templates without direct instruction on grammar, spelling, } \\
\text { and punctuation. }\end{array}$ \\
\hline 4c & Discourse strongly framed & $\begin{array}{l}\text { E.g. Teachers explicitly state what is required for text } \\
\text { production }\end{array}$ \\
\hline 4d & Discourse weakly framed & $\begin{array}{l}\text { E.g. Teachers allow students some control over what is } \\
\text { considered acceptable text production. }\end{array}$ \\
\hline 4e & $\begin{array}{l}\text { Instructional discourse embedded in } \\
\text { explicit regulative discourse }\end{array}$ & $\begin{array}{l}\text { E.g. Instructions about appropriate care of laptops become } \\
\text { part of the organisational segments of lessons. }\end{array}$ \\
\hline
\end{tabular}

\section{Figure 3 List of Codes with Examples}


This was facilitated by NVivo 9.0 software to retrieve the relevant researcher blogs, lesson observations, meeting transcripts, semi-structured interview transcripts, and reflective journal entries pertaining to each code, and to determine the most frequently repeated coding categories. We coded for all instances of a theme because the categories were not mutually exclusive. This coding and analysis enabled the development of propositions based on the relationships between categories leading to theory generation.

The regulative discourse is what Bernstein describes as the "moral discourse." It refers to the patterns of interaction that create order, roles, and relationships (Bernstein, 2000, p. 32). The instructional discourse pertains to the sequencing, pacing, and criteria of the content that is relayed, and whether these rules were either implicit or explicit. These coding patterns enabled us to identify the degree to which multimodal written communication reflected a "performance" or “competence" model (Bernstein, 2000). Performance and competence models are theoretical constructs for describing movement along a continuum as teachers change their orientations to time, space, and text. When orienting toward the performance model, teachers appear to have overt control over time, space, and text via the objectification of grades. However, in reality, teachers may have little pedagogic autonomy if strong external regulations from educational authorities or other stakeholders dominate. In short, the performance model specializes the division of labor for both teachers and students, and deviance by either is easy to detect (Bernstein, 2000).

Competence models of pedagogy tend toward implicit relations of control where the criteria of the pedagogic device are less explicit than in a performance model, and students have a greater measure of control over the selection, sequencing, and pacing of time, space, and text (see Cazden, 1995). In a competence model, teachers focus upon the personal intentions and dispositions of the students. Teachers who orient toward a competence model of pedagogy still respond to various demands from the educational authorities, but overall these teachers exercise greater autonomy. There are fewer tendencies for the assessment in a competence model to differentiate between categories of students in explicit ways (Bernstein, 2000). The archived written and digital texts produced by students provide evidence of the evaluative focus of the teachers and researchers in the digital media program and were necessary to support the teachers' teaching, learning, and assessment.

\section{Results}

Time

The digital program ordered time explicitly, with strongly teacher-controlled pacing. For example, in one 8-week period, each student created a large number of digital texts including a 
personal web profile, script and podcast (web video), blog (web log), movie page, images, paragraphs of text, and an event countdown using multiple new digital interfaces (e.g., iWeb, iPhoto, iMovie, widgets). A typical lesson constituted 10 to 15 minutes of direct instruction to introduce the aim of the lesson and demonstrate a new technology skill, followed by approximately 20 minutes of writing using laptops in pairs. The media specialist allocated 8 to 15 minutes for each student to have a turn to control the mouse or track pad while the other student observed. The lessons concluded with a short review of the skills taught, with brief organizational time to store the laptops, cameras, or both.

Opportunity for free exploration of the resources was less important, although students were permitted short periods of experimentation with visual software after they had produced the required texts. The teachers, rather than the students, determined the rate at which the digital writing performances were to be completed. Margaret scheduled extra time outside of the program to allow all students to complete and edit their textual products. Figure 4 is a singlepage excerpt from a larger two-page lesson observation, which included the allocation of time to different activities.

In relation to the social organization of time, the media specialist and teachers directed the students' use of time and the selection of writing practices, and the media-based lesson segments were repeatedly successful in gaining students' motivation and time on-task in comparison with tasks that involved print-based writing without digital tools. We coded time as strongly framed 2.5 times as often as weakly framed. Weaker and stronger framing of time are not normative categories, but refer to the locus of control of the time frame and learning process by students or teachers. Time is typically strongly classified by the teacher in performance models of instruction, which was what remained essentially unchanged prior to, and throughout, the project (Bernstein, 2000). Reflecting a performance model, the writing curriculum prioritized the future tense as the temporal modality because the program was oriented toward moving students rapidly through an ambitious set of new technical skills and creating texts in new genres. Time for students to construct their own pedagogic agendas was limited.

The significance of the regulated timing and pacing of the pedagogic dis- courses observed in these new writing lessons is that the act of pedagogizing new writing knowledge and communication skills specialized meanings to time. The social grammar of schooling influenced the transformation of new literacy knowledge and practice as it moved from specialist media work in industry domains, into pedagogic classroom communication. The new writing and text construction practices became recontextualized as official school knowledge, with all the institutional trapping of time and its regulation in schools through the pedagogic device (Moss, 2000). 
Summary of Time Allocations: This 1-hour lesson involved 8-15 minutes of writing time per student within the hour. 8-15 minutes were spent collaborating or watching peers using the shared laptop or following procedures for using the media applications. The remainder of the time was spent listening and watching direct instruction from the Whiteboard Smart (15 minutes), following procedures for allocating resources and using the media hardware/machines and for conducting lesson transition (15 minutes). The same lesson was observed three times with different classes, with variations noted.

\section{Background Experience of Learners}

Most of the students had never made their own web page before, and those who reported that they had, couldn't state when or where they did this.

\begin{tabular}{|c|c|c|}
\hline Time & Activity & Comment \\
\hline 10:00 & $\begin{array}{l}\text { Students allocated to pairs and } \\
\text { given a number, which matched } \\
\text { the number of the laptop. }\end{array}$ & $\begin{array}{l}\text { This is to ensure that the iWeb data on each laptop can be retrieved and users on } \\
\text { shared computers can find their own text from previous lessons. }\end{array}$ \\
\hline 10:05 & $\begin{array}{l}\text { Students opened and switched on } \\
\text { laptops after collecting them from } \\
\text { the media teacher. }\end{array}$ & $\begin{array}{l}\text { The students were familiar only with the Apple MacBook hardware used in } \\
\text { previous lessons. }\end{array}$ \\
\hline 10:07 & $\begin{array}{l}\text { Teacher shows magnified screen } \\
\text { using data projector and } \\
\text { whiteboard. Demonstrates how to: } \\
\text { Says: "Go to "Applications". } \\
\text { Teacher showed how scroll up } \\
\text { and down using the bar to find } \\
\text { "i-Web" icon. Select to open. } \\
\text { Students were given a moment to } \\
\text { follow each direction, and put } \\
\text { their hands on heads after } \\
\text { following each step. }\end{array}$ & $\begin{array}{l}\text { One teacher commented that maybe we need some keyboarding lessons, as } \\
\text { the students are typing with one index finger using one hand. There is } \\
\text { currently no whole school keyboarding skills program. Another } \\
\text { teacher also commented that maybe we could scaffold just a couple of } \\
\text { reminders for syntax, such as "Don't forget to use a capital letter at the } \\
\text { beginning of each line in the profile, after a colon, for your name, for titles, and } \\
\text { at the beginning of the sentences." The particular iWeb template required } \\
\text { completing a profile (blank fields such as Name, Birthday, Age, Favorite Book, } \\
\text { etc.) that involved many capitalized words. Overall, the teachers were really } \\
\text { happy about having these lessons and the support with technology use. }\end{array}$ \\
\hline 10:10 & $\begin{array}{l}\text { Choosing a template: Show how to } \\
\text { choose an existing web template } \\
\text { by scrolling through the template } \\
\text { icons displayed on the left of the } \\
\text { screen, and selecting a desirable } \\
\text { format. } \\
\text { Show how to highlight the "About } \\
\text { me" page of the template and } \\
\text { click on it twice to select (since } \\
\text { the program opens on a welcome } \\
\text { page by default). }\end{array}$ & $\begin{array}{l}\text { I observed that many of the children chose the two sites that were used in the } \\
\text { media teacher's example site, even though they had many others to choose from. } \\
\text { There were occasionally a lot of hands up at once, but no one had to wait more } \\
\text { than about } 10 \text { seconds for an adult to help in Margaret's class. Students in the } \\
\text { first two classes had their profiles to help scaffold the writing, though } \\
\text { few children reached the part of the template where substantial blocks of } \\
\text { writing were required. }\end{array}$ \\
\hline 10:20 & $\begin{array}{l}\text { Saving/Publish: Show how to } \\
\text { "click on site" on top left of } \\
\text { screen. Then click again to } \\
\text { highlight and type a name for the } \\
\text { document, using your own first } \\
\text { name. }\end{array}$ & $\begin{array}{l}\text { Clear instructions were given in small steps when all students were } \\
\text { watching. }\end{array}$ \\
\hline $10: 25$ & $\begin{array}{l}\text { Modify Template: Show how to } \\
\text { highlight sections of text to delete } \\
\text { and type in new text. Explain that } \\
\text { some sections will not be relevant, } \\
\text { such as "Occupation "or "Major", } \\
\text { so just delete these fields. } \\
\text { Demonstrate how to enter own } \\
\text { name into the "About Me" title. } \\
\text { Students take turns to modify } \\
\text { the text. In the second lesson, } \\
\text { the first member in each pair } \\
\text { started keyboarding at 10:25. } \\
\text { They finished at about 10:37. }\end{array}$ & $\begin{array}{l}\text { Some of the students were anxious to type, and didn't allow the first person to } \\
\text { work without interruption. Time was short in the second lesson, because the } \\
\text { first lesson ran over. } \\
\text { Students Comments: "This is fun". "I was almost finished and want to keep } \\
\text { going". "Can you help me, Miss?" When asked if anything was difficult about } \\
\text { the lessons, students }\end{array}$ \\
\hline
\end{tabular}

Figure 4 Excerpt of lesson observation (page 1 of 2). 
The organization of time in the writing curriculum also became specialized or focused to some degree by the introduction of digital practices. We coded 144 occurrences of time becoming specialized by the digital tools. Instruction in media applications (software) and use composed $42 \%$ of the total instructional time, and a further $10 \%$ to the use of the hardware. Time allocated to focused instruction in visual literacies, such as analyzing the multimodal features of screen displays for different target audiences, composed $36 \%$ of the instructional time. Some $73 \%$ of the program time involved forms of viewing texts on the screen, including both encoding and decoding in digital sites of display. Audio design constituted $10 \%$ of the instructional time, including tasks such as recording narration, selecting background digital music, and selecting sound effects. Instructions on screen-based genres and text features, such as the features of blogs and micro-documentaries, constituted $14 \%$ of the instructional time in the new media program. This can be contrasted to time apportioned to linguistic text production, such as handwriting drafts of narration or word processing paragraphs of texts on web pages, which constituted $44 \%$ of the learning time. This figure includes writing tasks in pairs using the laptops, though only one student at a time was able to control the text. When accounting only for individual time on-task and control of the text, $26 \%$ of the program time involved students' production of written words.

It was also observed that time was apportioned to making regulative discourses explicit about required behaviors with digital devices and media ( 26 occurrences). The relationship between time and the use of digital technologies was recursive - new digital practices were modified by the tight organization of time in the school and, conversely, reciprocally altered the existing ordering of the curriculum. With regard to the investment of time required to teach media-based new literacy practices, the teachers observed some changes during the program. The three teachers' responses were very similar, so we cite Margaret as an example:

Researcher: How has the allocation of time within your literacy curriculum changed since the media program began this year?

Margaret: In the beginning I felt that my math program was shortened to fit it all in, but now I am more into it all, the time is not a problem. I am more flexible and I fit things around things better.

Researcher: Have any of the costs of digital literacy work surprised you in terms of the time required (at any point this year)?

Margaret: In the beginning — yes! Now that teachers are fully planning the units and incorporating digital literacy into it, everything seems to complement each other. 
Researcher: Are you observing any changes in the allocation of time for literacy as the students become more proficient with the technologies? Margaret: Yes, it runs very smoothly now. Because the children are engaged and understand the end task and the work I've done to prepare them, the hands-on work with the computers is smooth and purposeful.

Teachers initially perceived the new digital writing practices that were modeled by the media specialists as too time-consuming, posing a challenge for teachers to adequately address other important objectives of the English curriculum. However, over the course of the project, teachers revisited and consolidated digital writing practices as a strategy to ensure that introducing the technical requisites of digital composition did not significantly shift the existing temporal rules of pedagogic practice in the school curriculum (Bernstein, 2000). We recorded 31 instances in which researchers or teachers noted that the amount of time students spent writing was increasing in comparison to the early lessons in which students needed

more time to learn to use the technologies and software systems that support writing. Over the course of the program, the regulative discourse of schooling not only recontextualized the content of pedagogic practice - that is, of new written communication knowledge and skillsbut recontextualized the theory of instruction, with its rules for the sequence and pacing of transmission.

Space

Space in the classrooms for the new writing program was more tightly controlled and structured (40 occurrences) than weakly controlled (31 occurrences). For example, the new writing lessons frequently began with students receiving direct instruction from the teacher, with the large electronic white-board providing a visual display. While the use of media was novel, the students were positioned as receivers, rather than as producers, of knowledge, with their gaze directed at the teacher and the screen. This use of space reflected an orientation to Bernstein's (2000) description of the "performance model" in which space is explicitly organized and regulated. These patterns are typical of teacher-initiated direct instruction, which frequently narrows the range of bodily displays of orientation by the students (Bezemer, 2008).

The potential for students to construct their own pedagogic space was limited, such as when students were seated at their desks listening to the teacher. However, we observed that teachers reordered the social space to accommodate some of the new written communication practices (63 occurrences in 120 lessons). For example, the textual practices of filming 
interviews, audio recording podcasts, and interviewing required opening up of the spatial boundaries that typically limited access and movement in the classroom. These practices created spatial meanings, such as the classroom acting as a filming studio, or the school grounds as the movie set. The practice of filming required the teachers to relinquish greater degrees of control over the construction of spaces as pedagogic sites. Jessica discussed this issue with the researcher:

Researcher: Did you find with having the children romping around the yard with video cameras, was that...

Jessica: A little bit scary!

Researcher: I remember that last year I taught a lesson and some of the kids were escaping. Having the boundaries of the classroom walls was a bit of a security. So did you see anything special about that ... that the kids ... that we could trust them to go outside.

Jessica: They were on task and it was exciting and appealing to them.

In this interview extract, the researcher refers to a conventional spelling lesson she had taught in the lead-up to the new literacy program in which the ordering of architectonic spaces - the material space such as the arrangement of furniture was tightly framed. Several students had "escaped" from the classroom - one to hide under a building and another to draw graffiti on the external walls. On several other occasions, the researcher had assisted an emergency squadron of specialist teachers and teacher aides to comb the schoolyard and beyond to locate these students. In contrast, during the project, the students would reliably capture video footage outside the classroom in groups with a supervising adult. When opening up these spaces, students did not escape teacher surveillance because of their intrinsic motivation to complete the project.

The collaborative nature of many group media projects, such as interviewing or filming, similarly required increased communication between peers, generating a new interactional order among the students. These dialogic spaces differed significantly to didactic teaching methods that emphasize vertical relations between teacher and students, and typically mark students as "blank slates" to be filled. At other times, the differentiation of the class- room space was tied to the specific technologies, such as audio recording of podcasts. Recording podcasts requires access to different areas of the classroom space to avoid noise interference from other groups. When asked about classroom space in the teacher interviews, Vivian cited audio recording as an example of when the use of the classroom space was significantly different from her typical English lessons: "During podcasting [audio recording] ... classroom space did change." 
Digitally mediated forms of representation, such as filming and podcasting, engendered increased student control over the construction of spaces as pedagogic sites, and the teachers' softening of the regulatory boundaries that previously limited access and movement in conventional literacy lessons. There was a diversified ordering of classroom space, in which students were more dispersed throughout a broadened set of indoor and outside spaces to meet their group needs, such as to film in specific locations. This was a consistent theme in our classroom observations, and confirmed in our dialogue with the teachers. For example, Jessica reported, "The student movement in my room is really not strict when using digital technologies, but is more so in other daily lessons."

The particular digital composition practices introduced in this project clearly positioned students as active agents who could transform the social and material classroom space.

During filming with digital cameras, interviewing, and recording audio and video podcasts, students were permitted to spatially disrupt the typical formalities of print-based writing lessons that we had observed in the months prior to the introduction of the new curriculum. There was a greater degree of movement, peer interactions, and group-defined action. Often this was tied to the necessities of the practice, whether for technical reasons, such as the logistics of audio recording within a whole-class context, or because some written communication practices involve collaboration between designers with different roles (e.g., filmmaking involves directors, camera crew, and a cast).

In our study, the process of teachers and researchers working together to embed digital writing practices in the curriculum necessitated new architectonic meanings of the classroom space, tangibly challenging the existing ideology of explicit teacher control and regulation. It demonstrates that certain digital forms of text production can destabilize the social order and the classroom space within the constraints of the maintenance and reproduction of the established hierarchies in the school. In this study, the disruption to the ordering of the classroom space was tied to the specific writing practice and its technologies of production, but which were nevertheless still ultimately governed by the regulative discourse of schooling (Bernstein, 2000).

\section{Text}

During the new curriculum the students' texts as embodied performances - their forms of sitting, moving, direction of gaze, and so on — were tightly controlled by the teachers and the media specialist, and this process of regulation consumed some organizational time in each lesson (5-10 minutes). The pedagogic text - the learning outcomes of pedagogic practicewas issued by both teachers and the media specialist in the form of tasks that afforded students little control over the selection, sequence, and pacing (63 occurrences in 120 
lessons). The new curriculum did not necessarily make links to the digital competencies that students possessed in their out-of-school digital contexts, such as online communication in video game playing, but remained school-based discourses (Mills, 2010).

During the introduction of the new curriculum, we observed a continued orientation toward a performance model of pedagogy in which the rules for legitimate texts to be produced by students were made explicit. We observed 61 occurrences in which the criteria for text production were explicit, in comparison to 6 instances in which the criteria were unclear or unspecified. For example, we observed a preference among the teachers and the media specialist to use step-by-step instructions rather than experimentation, and the tight sequencing and pacing of specialized digital skills to display writing. To produce documentaries, the students were required to reproduce precise textual features of the documentary script, vary shot types for different purposes, and perform specialized digital editing, such as digitally inserting cutaways into video footage. This is demonstrated in Figure 5, which is a typical lesson focusing on several technical procedures.

\section{Activity 2: 12:20}

This Lesson phase involved direct instruction about how to publish a podcast. The teacher used a data projector and whiteboard. Students were seated in pairs at desks watching. This instruction was given before the students moved to the computers. The students watched intently. In 4C's class, two boys had to sit on the floor under the screen, as there was not enough seating space at the desks for this larger class (28). Instructions for digital procedures were provided:

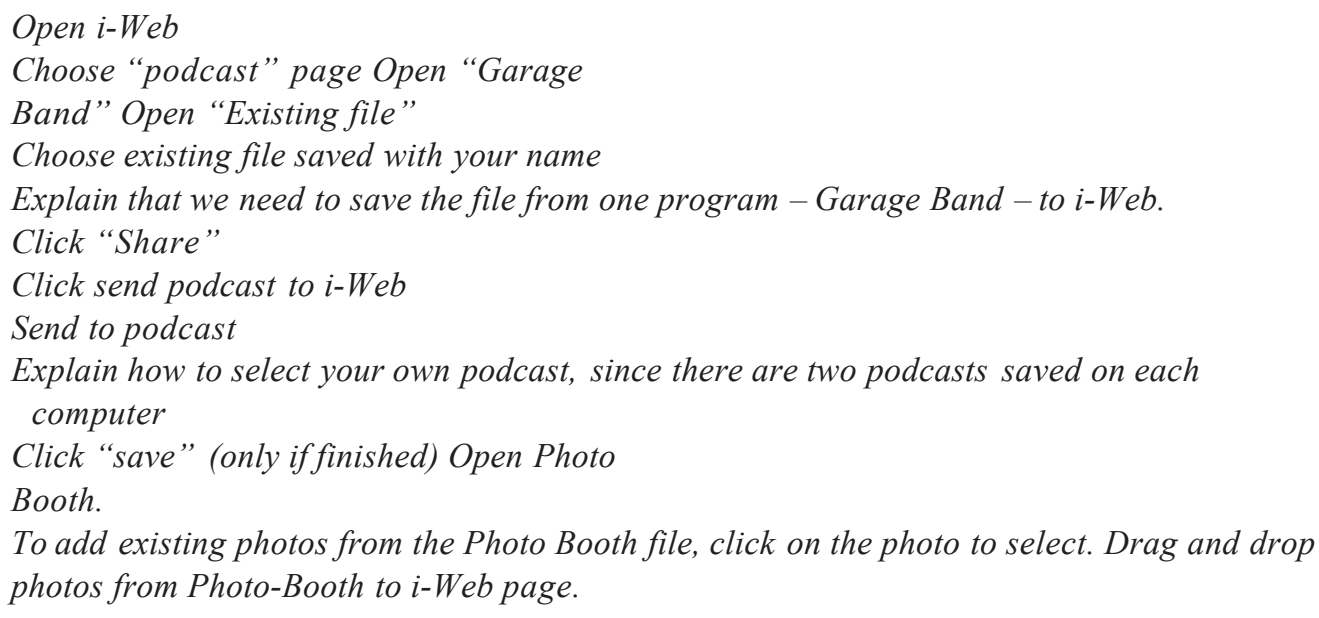

Figure 5 Excerpt of lesson observation-technical procedures. 
We see in this lesson excerpt that the pedagogic discourse was formulated as technical procedures that were clearly marked with respect to form and function. A good proportion of the criteria for text production were centered on reproducing digital text features. This is because the focus of the lessons by the media arts teacher was to introduce specialist knowledge of digital design and the use of technology tools-skills that are not ordinarily accessible to the classroom teachers and students. Teachers and the media specialist were explicit about the students' required performances during instruction. As demonstrated in the lesson above, the teacher rather than the students controlled the selection, sequencing, and pacing of the instruction. The students were required to reproduce the skills on their laptops. The digital texts were graded against criteria to enable teachers to differentiate between the qualities of the textual products (see Figure 6).

As seen in Figure 6, the evaluative rule of the digital writing program often emphasized the performance of digital skills over the linguistic elements of the design tasks (e.g., punctuation, spelling, capitalization, grammar, writing quantity). However, we also observed a shift from linguistic-based text criteria to one that included linguistic, visual, spatial, gestural, and audio assemblages and their integrated modes. For example, the students' web pages needed to include blogs, images, podcasts, online polls, and birthday countdown widgets (software embedded within other programs). Certain criteria addressed the "social function" of the genre and text type to be produced (Halliday \& Hasan, 1989), such as understanding the purpose of blogs to recount events (14\% of the time). While there were linguistic and multimodal elements in the students' texts, writing conventions, such as spelling and grammar, were taught incidentally, rather than explicitly and systematically.

The pedagogic text — the measure of learning — largely constituted the students' digital communication performances. Assigning grades or scores objectified some of these performances, although the mandated curriculum did not require the formal evaluation of the students' proficiency with the technologies of text production. The need for more explicit criteria for writing conventions, such as spelling and punctuation use, was a concern raised by the teachers in several interviews and planning meetings, particularly in the first semester of the second year. After these meetings, we were able to negotiate greater input from the teachers earlier in the planning of the digital writing program. 


\begin{tabular}{|c|c|c|c|c|c|}
\hline \multirow{3}{*}{ ELEMENTS } & \multicolumn{5}{|c|}{ Descriptors } \\
\hline & $\mathbf{A}$ & B & C & D & $\mathbf{E}$ \\
\hline & \multicolumn{5}{|c|}{ The student work demonstrates evidence of: } \\
\hline \multirow{3}{*}{ Knowledge } & $\begin{array}{l}\text { Comprehensive } \\
\text { knowledge and } \\
\text { understanding of } \\
\text { personal website } \\
\text { conventions, } \\
\text { utilizing the } \\
\text { template and a range } \\
\text { of modes (e.g. still } \\
\text { and moving images, } \\
\text { sounds and words). }\end{array}$ & $\begin{array}{l}\text { Good } \\
\text { knowledge and } \\
\text { understanding of } \\
\text { personal website } \\
\text { conventions, } \\
\text { utilizing the } \\
\text { template and a } \\
\text { range of modes (e.g. } \\
\text { still and moving } \\
\text { images, sounds and } \\
\text { words). }\end{array}$ & $\begin{array}{l}\text { Satisfactory } \\
\text { knowledge and } \\
\text { understanding of } \\
\text { personal website } \\
\text { conventions, } \\
\text { utilizing the } \\
\text { template some } \\
\text { modes (e.g. } \\
\text { Still and moving } \\
\text { images, sounds and } \\
\text { words). }\end{array}$ & $\begin{array}{l}\text { Variable knowledge } \\
\text { and understanding of } \\
\text { personal website } \\
\text { conventions, utilizing } \\
\text { the template and a } \\
\text { range of modes (e.g. } \\
\text { still and moving } \\
\text { images, sounds and } \\
\text { words). }\end{array}$ & $\begin{array}{l}\text { Rudimentary } \\
\text { knowledge and } \\
\text { understanding of } \\
\text { personal website } \\
\text { conventions, } \\
\text { without using the } \\
\text { template } \\
\text { or a range of } \\
\text { modes. }\end{array}$ \\
\hline & $\begin{array}{l}\text { Website shows a } \\
\text { deliberate and } \\
\text { effective selection } \\
\text { of words and } \\
\text { images to } \\
\text { represent self } \\
\text { through a website } \\
\text { to an audience. }\end{array}$ & $\begin{array}{l}\text { Website shows } \\
\text { deliberate } \\
\text { selection of words } \\
\text { and images to } \\
\text { represent self } \\
\text { through a website } \\
\text { to an audience. }\end{array}$ & $\begin{array}{l}\text { Website shows some } \\
\text { selection of } \\
\text { text/images to } \\
\text { represent self } \\
\text { through a website to } \\
\text { an audience. }\end{array}$ & $\begin{array}{l}\text { Website shows a } \\
\text { variable selection } \\
\text { of words and } \\
\text { images to } \\
\text { represent self } \\
\text { through a website } \\
\text { to an audience. }\end{array}$ & $\begin{array}{l}\text { Website shows poor } \\
\text { selection of } \\
\text { images and few } \\
\text { words } \\
\text { to represent self } \\
\text { through a website } \\
\text { to an audience. }\end{array}$ \\
\hline & $\begin{array}{l}\text { Text shows above } \\
\text { average knowledge } \\
\text { of linguistic } \\
\text { conventions - text } \\
\text { structures, } \\
\text { grammar, } \\
\text { punctuation, } \\
\text { vocabulary and } \\
\text { spelling. }\end{array}$ & $\begin{array}{l}\text { Text shows good } \\
\text { knowledge of } \\
\text { linguistic } \\
\text { conventions - text } \\
\text { structures, } \\
\text { grammar, } \\
\text { punctuation, } \\
\text { vocabulary and } \\
\text { spelling. }\end{array}$ & $\begin{array}{l}\text { Text shows sound } \\
\text { knowledge of most } \\
\text { linguistic } \\
\text { conventions - text } \\
\text { structures, grammar, } \\
\text { punctuation, } \\
\text { vocabulary and } \\
\text { spelling. }\end{array}$ & $\begin{array}{l}\text { Text shows poor } \\
\text { knowledge } \\
\text { of linguistic } \\
\text { conventions } \\
\text { - text structures, } \\
\text { grammar, } \\
\text { punctuation, } \\
\text { vocabulary and } \\
\text { spelling. }\end{array}$ & $\begin{array}{l}\text { Test shows very } \\
\text { poor knowledge } \\
\text { of linguistic } \\
\text { conventions - text } \\
\text { structures, } \\
\text { grammar, } \\
\text { punctuation, } \\
\text { vocabulary } \\
\text { and spelling. }\end{array}$ \\
\hline Application & $\begin{array}{l}\text { Creative and } \\
\text { competent } \\
\text { creation of } \\
\text { text to express } \\
\text { ideas by selecting } \\
\text { and combining } \\
\text { text elements, } \\
\text { techniques, skills } \\
\text { and processes. }\end{array}$ & $\begin{array}{l}\text { Creative and } \\
\text { competent } \\
\text { creation of } \\
\text { text to express } \\
\text { ideas by selecting } \\
\text { and combining } \\
\text { text elements, } \\
\text { techniques, skills } \\
\text { and processes. }\end{array}$ & $\begin{array}{l}\text { Satisfactory creation } \\
\text { of text } \\
\text { to express ideas by } \\
\text { selecting } \\
\text { and combining arts } \\
\text { elements, } \\
\text { techniques, skills } \\
\text { and processes. }\end{array}$ & $\begin{array}{l}\text { Variable creation of } \\
\text { text to express ideas } \\
\text { using arts elements, } \\
\text { techniques, skills } \\
\text { and processes with } \\
\text { teacher support. }\end{array}$ & $\begin{array}{l}\text { Shows very poor } \\
\text { evidence of text } \\
\text { elements, } \\
\text { techniques, skills } \\
\text { and processes, } \\
\text { even with teacher } \\
\text { support. }\end{array}$ \\
\hline $\begin{array}{c}\text { About Me } \\
\text { Page }\end{array}$ & $\begin{array}{l}\text { About Me Page } \\
\text { shows skilful } \\
\text { inclusion and } \\
\text { manipulation of: } \\
\text { - Background } \\
\text { templates } \\
\text { - Associated text } \\
\text { and images } \\
\text { (added and } \\
\text { deleted) } \\
\text { - Photos } \\
\text { - Countdown } \\
\text { widget }\end{array}$ & $\begin{array}{l}\text { About Me Page } \\
\text { shows inclusion } \\
\text { and manipulation } \\
\text { of: } \\
\text { - Background } \\
\text { templates } \\
\text { - Associated text } \\
\text { and images } \\
\text { (added and } \\
\text { deleted) } \\
\text { - Photos } \\
\text { - Countdown } \\
\text { widget }\end{array}$ & $\begin{array}{l}\text { About Me Page } \\
\text { shows inclusion of: } \\
\text { - Background } \\
\text { templates } \\
\text { - Associated text } \\
\text { and images } \\
\text { (added and } \\
\text { deleted) } \\
\text { - Photos } \\
\text { - Countdown } \\
\text { widget }\end{array}$ & $\begin{array}{l}\text { About Me Page } \\
\text { shows some } \\
\text { inclusion of: } \\
\text { - Background } \\
\text { templates } \\
\text { - Associated text } \\
\text { and images } \\
\text { (added and } \\
\text { deleted) } \\
\text { - Photos } \\
\text { - Countdown } \\
\text { widget }\end{array}$ & $\begin{array}{l}\text { About Me Page } \\
\text { shows no evidence } \\
\text { of: } \\
\text { - Background } \\
\text { templates } \\
\text { - Associated text } \\
\text { and images } \\
\text { (added and } \\
\text { deleted) } \\
\text { - Photos } \\
\text { - Countdown } \\
\text { widget }\end{array}$ \\
\hline
\end{tabular}




\begin{tabular}{|c|c|c|c|c|c|}
\hline \multirow{3}{*}{ ELEMENTS } & \multicolumn{5}{|c|}{ Descriptors } \\
\hline & A & B & $\mathrm{C}$ & D & $\mathbf{E}$ \\
\hline & \multicolumn{5}{|c|}{ The student work demonstrates evidence of: } \\
\hline Blog Page & $\begin{array}{l}\text { Blog Page shows } \\
\text { skilful inclusion and } \\
\text { manipulation of: } \\
\text { - Blog text } \\
\text { structure } \\
\text { - Associated text } \\
\text { and images } \\
\text { (added and } \\
\text { deleted) } \\
\text { - Fonts and colours } \\
\text { of text and } \\
\text { graphics }\end{array}$ & $\begin{array}{l}\text { Blog Page shows } \\
\text { good inclusion } \\
\text { and manipulation } \\
\text { of: } \\
\text { - Blog text } \\
\text { structure } \\
\text { - Associated text } \\
\text { and images } \\
\text { (added and } \\
\text { deleted) } \\
\text { - Fonts and } \\
\text { colours of text } \\
\text { and graphics }\end{array}$ & $\begin{array}{l}\text { Blog Page shows } \\
\text { inclusion of: } \\
\text { - Blog text } \\
\text { structure } \\
\text { - Associated text } \\
\text { and images } \\
\text { (added and } \\
\text { deleted) } \\
\text { - Fonts and colours } \\
\text { of text and } \\
\text { graphics }\end{array}$ & $\begin{array}{l}\text { Blog Page shows } \\
\text { some inclusion of: } \\
\text { - Blog text } \\
\text { structure } \\
\text { - Associated text } \\
\text { and images } \\
\text { (added and } \\
\text { deleted) } \\
\text { - Fonts and colours } \\
\text { of text and } \\
\text { graphics }\end{array}$ & $\begin{array}{l}\text { Blog Page shows } \\
\text { no evidence of: } \\
\text { - Blog text } \\
\text { structure } \\
\text { - Associated text } \\
\text { and images } \\
\text { (added and } \\
\text { deleted) } \\
\text { - Fonts and } \\
\text { colours of text } \\
\text { and graphics }\end{array}$ \\
\hline $\begin{array}{l}\text { Podcast } \\
\text { Page }\end{array}$ & $\begin{array}{l}\text { Podcast Page shows } \\
\text { skilful inclusion and } \\
\text { manipulation of: } \\
\text { - A podcast created } \\
\text { on Garageband } \\
\text { and exported into } \\
\text { iWeb } \\
\text { - Associated text } \\
\text { and images }\end{array}$ & \begin{tabular}{|} 
Podcast Page shows \\
good inclusion and \\
manipulation of: \\
- A podcast created \\
on Garageband \\
and exported into \\
iWeb \\
- Associated text \\
and images
\end{tabular} & $\begin{array}{l}\text { Podcast Page shows } \\
\text { inclusion of: } \\
\text { - A podcast created } \\
\text { on Garageband } \\
\text { and exported into } \\
\text { iWeb } \\
\text { - Associated text } \\
\text { and images }\end{array}$ & $\begin{array}{l}\text { Podcast Page } \\
\text { shows some } \\
\text { inclusion of: } \\
\text { - A podcast created } \\
\text { on Garageband } \\
\text { and exported into } \\
\text { iWeb } \\
\text { - Associated text } \\
\text { and images }\end{array}$ & $\begin{array}{l}\text { Podcast Page } \\
\text { shows no } \\
\text { evidence of: } \\
\text { - A podcast } \\
\text { created on } \\
\text { Garageband and } \\
\text { exported into } \\
\text { iWeb } \\
\text { - Associated text } \\
\text { and images }\end{array}$ \\
\hline Movie Page & $\begin{array}{l}\text { Movie Page shows } \\
\text { skilful inclusion and } \\
\text { manipulation of: } \\
\text { - iSight widget to } \\
\text { create } \\
\text { a webcam } \\
\text { movie on page } \\
\text { - Associated text } \\
\text { and images }\end{array}$ & $\begin{array}{l}\text { Movie Page shows } \\
\text { inclusion and } \\
\text { manipulation of: } \\
\text { - iSight widget to } \\
\text { create } \\
\text { a webcam } \\
\text { movie on page } \\
\text { - Associated text } \\
\text { and images }\end{array}$ & $\begin{array}{l}\text { Movie Page shows } \\
\text { inclusion of: } \\
\text { - iSight widget to } \\
\text { create } \\
\text { a webcam } \\
\text { movie on page } \\
\text { - Associated text } \\
\text { and images }\end{array}$ & $\begin{array}{l}\text { Movie Page shows } \\
\text { some inclusion } \\
\text { of: } \\
\text { - iSight widget to } \\
\text { create } \\
\text { a webcam } \\
\text { movie on page } \\
\text { - Associated text } \\
\text { and images }\end{array}$ & $\begin{array}{l}\text { Movie Page } \\
\text { shows no } \\
\text { evidence of: } \\
\text { - iSight widget } \\
\text { to create a } \\
\text { webcam } \\
\text { movie on page } \\
\text { - Associated text } \\
\text { and images }\end{array}$ \\
\hline
\end{tabular}

\section{Figure 6 Rubric for web pages.}

Note: See the appendix.

The teachers began to feel more confident to address linguistic elements in the students' digital texts during the collaborative lessons, and reported occasions where they had taught additional lessons to address editing of linguistic elements in the web-based writing.

Jessica: If I had been doing the lessons on my own, there would have been more emphasis on the language elements in the writing, and then students can put that into the media. I found that they were just writing quickly to get on to the computers, and to use the technologies and cameras. The expectations that I would have had in their general writing would have been at a higher level if it were a more formal writing lesson. 
Researcher: So you would have liked to see more explicit criteria for the print-based grammar, and syntax and semantics, as opposed to the technology and new media tools.

Jessica: Yes. And that's why I think that introducing the new technologies over a longer period of time would have worked better.

These data reflect the teacher's ideological struggle — a conflict between the evaluative rules of new literacy instruction and the print-based evaluative rules of the conventional English curriculum. As the discourse of digital design moved from its original site, in the world outside of schools, to its new positioning as pedagogic discourse in an elementary school English curriculum, a space was created in which ideologies were challenged. The evaluative criteria for the new literacy practices, such as video production and visual design tasks, were perceived by teachers to be misaligned at times with the evaluative criteria of the existing English curriculum. There was a struggle to see linguistic design as part of media design and vice versa, and to integrate these design elements in written communication.

As the responsibility for the curriculum was gradually released to the teachers in the second semester of the second year, the evaluative rule become more closely aligned with the existing writing curriculum, giving priority to linguistic textual features over the introduction of new media (e.g., digital software) and modes (e.g., visual, gestural, spatial, audio). For example, over several months, we observed the teachers taking a greater role in determining the evaluative rule for the digital products, such as choosing digital products that had the greatest convergence with the genres and text types addressed in their existing English curriculum program.

In the last semester of the second year, the teachers unanimously decided to revisit the Apple iWeb software, requiring the students to create narratives in blank web page templates (see Figure 7).

This shifted the emphasis of the evaluative rule from digital skills, which became backgrounded, to the linguistic features of narratives. In a final interview when the teachers had regained full control of the English curriculum, we asked if they had managed to integrate multimodal instruction. Jessica responded:

Not purely at this stage. I think, what would be perfect, is the students have a really good knowledge of the basics of how to use the media... The best thing would be to work more on the English side; and embed some of the digital elements, knowing that you didn't have to spend so much time on "This is how you turn a computer on. This is how you log on." 
Here, Jessica identified a conflict between the evaluative rules of the digital writing classroom, particularly the skills involved in using different media, and those of a predominantly print-based writing curriculum. We would argue that this conflict also existed in terms of the additional multimodal semiotic knowledge of web-based texts - the modes and grammars of visual, spatial, audio design — that needed to be taught to students ( $46 \%$ of instructional time). The pedagogic discourse of schooling had not fully refocused the discourse of digital design across modes and media. This was evident when Jessica talked about "the English side," to which she was referring to print-based practices of text

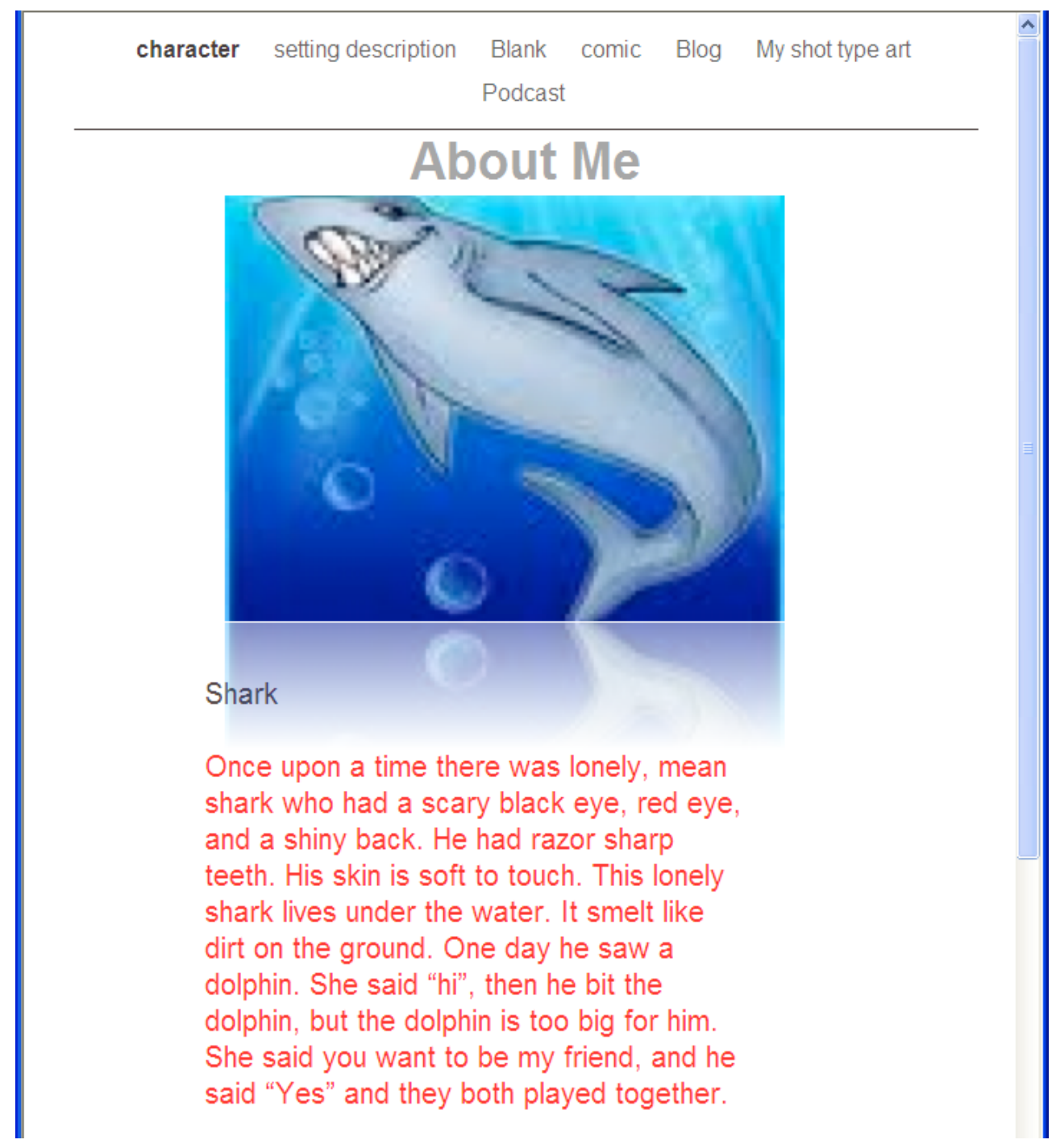

Figure 7. Student text sample: page 1 of 3 
construction. This is a common conception of new literacy practices among teachers, which is the view that elevates conventional literacies over digital and multimodal writing practices. Leander (2009) explains that this view is sustained by compulsory national testing because digital communication practices are peripheral to the increasingly assessed business of printliteracy practice in elementary schools. A caveat is that national testing formats can sometimes include students' multimodal design of digital texts, but currently such elements are not part of the national testing of writing in Australia (MCEECDYA, 2012).

The selection, relation, sequence, and pace for introducing specialist digital and multimodal design competencies into the writing curriculum were a function of embedding the instructional discourse into the regulative discourse through the pedagogic act (Bernstein, 2000). The regulative discourse and its evaluative rules governed what aspects of multimodal and digital design did or did not constitute writing and literacies (27 occurrences in 120 lessons). For example, while the teachers and researchers worked together to develop a set of rubrics or criterion-referenced assessments to grade the students' web pages, digital stories, online comics, podcasts, and other multimodal creations, only Margaret provided the students with time to edit and display their texts, and utilized this assessment information in formal school-based reporting. Jessica and Vivian left the students' multimodal writing samples unfinished and unassessed in their school reporting because it was their belief that the digital compositing content and criteria were not aligned to the prescribed state curriculum.

\section{Discussion}

While a collaborative approach to pedagogical reform was upheld throughout this study, and brought about transformation of writing practices in the curriculum, a conflict was created with the increasing need to address a much broadened range of texts across multiple technologies, media, modes, text formats, and social contexts. Theorists have argued that innovative media production and multimodal design are significantly more difficult to assess in traditional, low-cost formats of literacy curricula and externally imposed standardized assessments (Mills, 2010; Street, 2005). Consequently, many features of multimodal and digital text creation remain untapped by standardized literacy tests (Luke, 2008).

This is the tension between the evaluative rule of mandated testing of writing skills - the official recontextualizing field created and dominated by the state - and the differing evaluative rules for assessing multimodal text creation. This militated against the comprehensive pedagogic transformation of the curriculum. In Australia, the omission of 
digital and multimodal production in national testing ironically conflicts with the new inclusion of multimodal design in the recently introduced national English Curriculum (ACARA, 2014). Writing in its various forms carries with it epistemologies and values that are deeply embedded in disciplinary and cultural practices (Ackerman, 1993). Without the wholesale transformation of the evaluative rules for writing throughout all levels of the system, the instructional and pedagogic discourse of schooling will continue to relegate the broadened range of semiotic codes and media production skills to the margins of the elementary English curriculum.

Our findings demonstrated that the pedagogic device or cultural relay of schooling regulated, to some extent, how digital and multimodal writing and communication practices were embedded in the English curriculum in a low socioeconomic status and culturally diverse elementary school. The changes created an ideological struggle as digital text production practices and multi-modal grammars were adapted from broader societal fields to meet the instructional and regulative discourses of a conventional writing curriculum that prioritized written words in paperbound textual formats.

The team's embedding of a broadened range of multimodal composition using different media practices within the English curriculum recontextualized time, space, and text. During the final months of the project, we observed that despite some incremental changes to three teachers' content and practices, the existing cultural relay of schooling largely influenced and con- strained any fundamental changes to the ordering of curriculum time and classroom space and the evaluative rule of the required texts. However, we also observed subtle differences to the regulative discourse used by teachers, with certain digital practices such as audio recording, involving different practical requirements, such as access to quiet spaces or rooms away from other noise interference. It was also observed that the teachers more readily took hold of new digital and multimodal text production practices that were more closely aligned to the requirements of writing in the national literacy test. We argue that in respect to evaluative rules, the reproduction of existing practices was in part tied to the historically established regulative discourse of schooling, maintained by government agencies, through the inherent nature of pedagogic acts in contexts of institutional power.

Our findings from this study generate understandings of the dialectic relations of pedagogic time and space in classrooms to the product of the pedagogic device when teachers take up digital writing practices within the elementary school curriculum. As argued, when transforming modes of practice in the curriculum, the selection of curriculum content, and the ordering and expected speed of students' progression through the revised curriculum, can be theorized as a function of the instructional discourse becoming embedded by researchers and teachers within the regulative discourse. This occurred through pedagogic acts of the teaching 
team to produce texts that met similar, yet different, evaluative rules to the sanctioned curriculum (Bernstein, 2000). It highlights the need for a reordering of time, space, and textthe principles of the pedagogic discourse - to embed multimodal design into conventional literacy curricula. There were initial heavy investments of time in the acquisition of digital skills and multimodal textual knowledge, a reordering of the classroom space for certain media production practices, and the detailed development of new evaluative rules and criteria for assessing the quality of the students' digital text creations.

We acknowledge that future teacher-research collaborations to embed digital writing practices within the elementary school curriculum may unfold in somewhat different ways, tied to changing historical, cultural, technological, political, and economic factors that influence social action in schools. This is not an account to demonstrate the extent to which researchers can collaborate with teachers to shift pedagogic practice. We have focused our analysis on the necessary ordering and reordering of time, space, and text in the context of a pedagogical reform, drawing on Bernstein's theories of the pedagogic device, to explain how new instructional discourses of multimodal and media design became embedded in the regulative discourse of schooling by researchers and teachers, within the existing English curriculum in a socially disadvantaged Australian school.

The pervasiveness, convergence, and increased accessibility of digital technologies for multimodal writing call for an extension of the boundaries of what constitutes writing practices in schools. As Dalton and colleagues (2011) have argued, writing programs often include technology as an add-on to a print-based curriculum approach, with teachers feeling underprepared to teach digital writing effectively with technology. Perhaps more importantly, teachers need expanded knowledge of multimodal semiotics, including visual, audio, spatial, gestural, and linguistic elements, to encompass the full range of design grammars involved in digital composition using various media.

While some schooling authorities have begun to include multimodal and digital text production in standardized English assessments, this is currently the exception rather than the rule. It is timely for governing agencies to reconsider the changing nature of writing across levels of schooling, and to reconsider the necessary shifts to curriculum time, classroom social space, and development of evaluative criteria to accommodate new specialist forms of digital text creation. The systematic and continual inclusion of writing in digital formats and specialist discourses of written communication needs to become a fundamental part of transformed evaluative criteria, particularly in contexts of externally imposed national and state-wide testing where what is not tested is not privileged. 


\section{Appendix}

Notes on Technical Terms used in Figure 6

\section{Terms}

Widget

Countdown widget

$\mathrm{B} \log$

Podcast

GarageBand

iWeb

iSight widget

Webcam movie

\section{Definition}

A web widget or widget is a small and helpful software application that can be embedded directly into a web page.

An easy to use web application or clock that can be used to count remaining days until an important event on the calendar.

A series of discrete entries or posts published on the World Wide Web that is typically displayed in reverse chronological order and may take a variety of generic forms for different social purposes (e.g., recount, argue, narrative, share images).

An audio recording or video recording made available in digital format for automatic download from the Internet.

An Apple software application for OS X and iOS that allows users to create music or podcasts.

Website creation software from Apple.

A small Apple software application to record and place short video directly into your web page, used with a webcam.

A movie created using a webcam or video camera used to stream digital video through a computer or computer network.

\section{Acknowledgments}

The authors would like to thank the research partners, the Queensland Teachers' Union, the staff, students, and community of the school where the research is based, and the media teacher, Ms Amanda Levido.

\section{Declaration of Conflicting Interests}

The author(s) declared no potential conflicts of interest with respect to the research, authorship, and/or publication of this article.

\section{Funding}

The author(s) disclosed receipt of the following financial support for the research, authorship, and/or publication of this article: This research work was supported by the Australian Research Council Linkage Scheme Project LP0990289, with Annette Woods, Allan Luke, and colleagues. The views expressed herein are those of the authors, and are not necessarily those of the Australian Research Council. 


\section{References}

Ackerman, J. M. (1993). The promise of writing to learn. Written Communication, 10(3), 334-370.

Adams, B. (1995). Timewatch: The social analysis of time. Cambridge, UK: Polity.

Applebee, A., \& Langer, J. (2009). What is happening in the teaching of writing. English Journal, 98(5), 18-28.

Australian Bureau of Statistics. (2006). Census of population and housing: Selected social and housing characteristics Australia and statistics local areas: Logan. Canberra: Australian Government.

Australian Curriculum, Assessment and Reporting Authority. (2012). National Assessment Program-Literacy and Numeracy (NAPLAN). Retrieved from http://www.qsa.qld.edu.au/testing/357tests/news.html

Australian Curriculum, Assessment and Reporting Authority. (2014). Australian curriculum —English Version 6.0. Canberra: Australian Government.

Barton, D. (2001). Directions for literacy research: Analysing language and social practices in a textually mediated world. Language and Education, 15(2-3), 92-104.

Bennett, S., \& Maton, K. (2010). Beyond the "digital natives" debate: Towards a more nuanced understanding of students' technology experiences. Journal of Computer Assisted Learning, 26(5), 321-331.

Bernstein, B. (1990). Class, codes, and control: The structuring of pedagogic dis- course (Vol. 4). London, UK: Routledge.

Bernstein, B. (2000). Pedagogy, symbolic control and identity: Theory, research, and critique. Oxford, UK: Rowman \& Littlefield.

Bezemer, J. (2008). Displaying orientation in the classroom: Students' multimodal responses to teacher instructions. Linguistics and Education, 19(2), 166-178.

Brown, A., Ash, D., Rutherford, M., Nakagawa, K., Gordon, A., \& Campione, J. C. (1993). Distributed expertise in the classroom. In G. Salomon (Ed.), Distributed cognitions: Psychological and educational considerations (pp. 188-228). New York, NY: Cambridge University Press.

Buckingham, D. (2007). Digital media literacies: Rethinking media education in the age of the Internet. Research in Comparative and International Education, 2(1), 43-55.

Carspecken, P. (1996). Critical ethnography in educational research: A theoretical and practical guide. New York, NY: Routledge.

Cazden, C. (1995). Visible and invisible pedagogies in literacy education. In P. Atkinson, B. Davies, \& S. Delamont (Eds.), Discourse and reproduction: Essays in honour of Basil Bernsteinz (pp. 161-174). New York, NY: Hampton Press.

Chandler-Olcott, K., \& Mahar, D. (2003). Tech-savviness meets multiliteracies: Exploring adolescent girls' technology-mediated literacy practices. Reading Research Quarterly, 38(3), 356-385.

Christie, F. (1999). The pedagogic device and the teaching of English. In F. Christie (Ed.), Pedagogy and the shaping of consciousness (pp. 156-184). London, UK: Cassell.

Comber, B., \& Nixon, H. (2008). Spatial literacies: Emergent pedagogies. Pedagogies: An 
International Journal, 3(4), 221-240.

Cope, B., \& Kalantzis, M. (2000). Multiliteracies: Literacy learning and the design of social futures. South Yarra, Australia: Macmillan.

Council of Australian Governments. (2009). National partnerships agreement on low socioeconomic status school communities. Canberra: Australian Government. Retrieved from http://www.coag.gov.au/

Courtland, M., \& Paddington, D. (2008). Digital literacy in a grade 8 classroom: An ezine webquest. Language and Literacy: A Canadian E-Journal, 10(1). Retrieved from http://ejournals.library.ualberta.ca/index.php/langandlit/article/ view/9773

Dalton, B., Proctor, C., Uccelli, P., Mo, E., \& Snow, C. E. (2011). Designing for diversity: The role of reading strategies in interactive vocabulary in a digital reading environment for fifth-grade monolingual English and bilingual students. Journal of Adolescent and Adult Literacy, 43(1), 68-100.

Exley, B., \& Richard-Bossez, A. (2013). The ABCs of teaching alphabet knowl- edge: Affordances and challenges of "weaving" visible and invisible pedagogies. Contemporary Issues in Early Childhood, 14(4), 345-356.

Grant, L. (2006). Using wikis in school: A case study. London, UK: Future Lab. Hagood, M. C. (2003). New media and online literacies: No age left behind. Reading Research Quarterly, 38(3), 387-391.

Halliday, M. A. K., \& Hasan, R. (1989). Language, context, text: Aspects of language in a social, semiotic perspective. Oxford, UK: Oxford University Press.

Heath, S. (1983). Ways with words: Language, life and work in communities and classrooms. Cambridge, UK: Cambridge University Press.

Helgøy, I., Homme, A., \& Gewirtz, S. (2007). Introduction to special issue: Local autonomy or state control? Exploring the effects of new forms of regulation in education. European Educational Research Journal, 6(3), 198-202.

Horst, H. A. (2009). From MySpace to Facebook: Coming of age in networked public culture. In I. Mizuko, S. Baumer, M. Bittanti, D. Boyd, R. Cody, B. Herr, et al. (Eds.), Hanging out, messing around, geeking out: Living and learning with new media (pp. 8399). Cambridge, MA: MIT Press.

Jewitt, C. (2008). Multimodality and literacy in school classrooms. Review of Research in Education, 32(1), 241-267.

Knobel, M., \& Lankshear, C. (Eds.). (2007). A new literacies sampler (Vol. 29). New York, NY: Peter Lang.

Kress, G. (2000). Multimodality. In B. Cope \& M. Kalantzis (Eds.), Multiliteracies: Literacy learning and the design of social futures (pp. 182-202). South Yarra, Australia: Macmillan.

Lam, E. W. S. (2009). Multiliteracies on instant messaging in negotiating local, translocal, and transnational affiliations: A case of an adolescent immigrant. Reading Research Quarterly, 44(4), 377-397.

Lankshear, C. (with Gee, J. P., Knobel, M., \& Searle, C.). (1997). Changing litera- cies. Philadelphia, PA: Open University Press.

Leander, K. (2003). Writing travellers' tales on new literacyscapes. Reading Research Quarterly, 38(3), 392-397. 
Leander, K. (2009). Composing with old and new media: Toward a parallel peda- gogy. In V. Carrington \& M. Robinson (Eds.), Digital literacies: Social learning and classroom practices (pp. 147-164). Thousand Oaks, CA: Sage.

Leander, K., \& Sheehy, M. (Eds.). (2004). Spatializing literacy research. New York, NY: Peter Lang.

Lefebvre, H. (1991). The production of space (D. Nicholson-Smith, Trans.). Cambridge, UK: Blackwell.

Lemke, J. (1998). Multiplying meaning: Visual and verbal semiotics in scientific text. In J. R. Martin \& R. Veel (Eds.), Reading science: Critical and functional per-spectives on discourses of science (pp. 87-114). London, UK: Routledge.

Luke, A. (2008). Digital innovation in schooling: Policy efficacy, youth cultures and pedagogical change. Brisbane, Australia: Queensland University of Technology.

Luke, A., \& Freebody, P. (1997). Shaping the social practices of reading. In S. Muspratt, A. Luke, \& P. Freebody (Eds.), Constructing critical literacies: Teaching and learning textual practice (pp. 185-225). Sydney, Australia: Allen \& Unwin.

Mills, K. A. (2010). A review of the digital turn in the New Literacy Studies. Review of Educational Research, 80(2), 246-271.

Mills, K.A. (2010b). Filming in progress: New spaces for multimodal designing. Linguistics and Education, 21(1), 14-28.

Ministerial Council for Education, Early Childhood Development and Youth Affairs. (2012). National Assessment Program Literacy and Numeracy. Retrieved from http:www.naplan.edu.au/home page.html

Moss, G. (2000). Informal literacies and pedagogic discourse. Linguistics and Education, 11(1), 47-64.

New London Group. (2000). A pedagogy of multiliteracies: Designing social futures. In B. Cope \& M. Kalantzis (Eds.), Multiliteracies: Literacy learning and the design of social futures (pp. 9-38). South Yarra, Australia: Macmillan.

Ranker, J. (2008). Making meaning on the screen: Digital video production about the Dominican Republic. Journal of Adolescent and Adult Literacy, 51(5), 410-422.

Singh, P. (1993). Institutional discourse and practice: A case study of the social construction of technological competence in the primary classroom. British Journal of the Sociology of Education, 14(1), 39-58.

Soja, E. W. (1989). Postmodern geographies: The reassertion of space in critical social theory. Oxford, UK: Verso.

Street, B. V. (2003). What's "new" in New Literacy Studies? Critical approaches to literacy in theory and practice. Current Issues in Comparative Education, 5(2), 77-91.

Street, B. V. (2005). Recent applications of New Literacy Studies in educational contexts. Research in the Teaching of English, 39(4), 417-423.

Suhr, K. A., Hernandez, D. A., Grimes, D., \& Warschauer, M. (2010). Laptops and fourthgrade literacy: Assisting the jump over the fourth-grade slump. Computing, 9(5), 5-43.

Unsworth, L. (2006). E-literature for children: Enhancing digital literacy learning.

London, UK: Routledge.

\section{Author Biographies}

Kathy A. Mills is a Principal Research Fellow (Australian Research Council) and Associate Professor of writing and literacy pedagogy in education at the Queensland University of 
Technology, Australia. Her research has extended understandings of children's multimodal sign-making practices in digital contexts of use, and developed pedagogies for multimodal literacy with marginalized groups.

Beryl Exley is an Associate Professor of writing and literacy education at the Queensland University of Technology. Her research work spans English curriculum and literacies in the primary and middle years curricula. She has been a chief investigator on an Australian Research Council Linkage grant documenting a digital writing intervention project in a low SES school. 